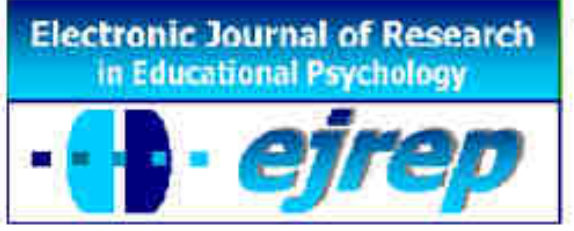

\title{
Educational assistance to improve reflective practice among student teachers
}

\section{Teresa Mauri ${ }^{1}$, Marc Clarà ${ }^{2}$, Rosa Colomina ${ }^{1}$, Javier Onrubia ${ }^{1}$}

${ }^{1}$ Department of Cognition, Developmental and Educational Psychology, University of Barcelona, Barcelona

${ }^{2}$ Department of Pedagogy and Psychology, University of Lleida, Lleida

Spain

Correspondence: Teresa Mauri. P. de la Valld'Hebron, 171, 08035, Barcelona. Spain. E-mail: teresamauri@ub.edu

(C) Education \& Psychology I+D+i and Ilustre Colegio Oficial de la Psicología de Andalucía Oriental (Spain) 


\begin{abstract}
Introduction. Recent educational research suggests that joint reflection can enhance student teachers' reflections on their own practice if they have adequate tutor support. This study aims to identify and characterize the assistance offered by college tutors in situations of joint reflection and analyses their contribution to the development of students' ability to reflect on their teaching practice. More specifically, we aim to identify the kind of tutor assistance that best helps students to develop their reflective capacity and to understand the situations they encounter during teaching practice.
\end{abstract}

Method. The research uses a case-study design to analyse the process of joint reflection engaged in by two groups of student teachers (13 and 15 students) with the assistance of their university tutors over five weeks of a teaching practice module. Data in the form of video recordings were subjected to two kinds of analysis: interactivity analysis and content analysis, both with the aim of examining the assistance offered by tutors in relation to reflective practice.

Results. Each tutor distributed assistance in a specific way, focusing on different characteristics of reflection and prioritizing intervention in particular dimensions of it. Differences were also observed in the type and amount of assistance offered in each dimension of reflection. The tutors also differed in the extent to which their assistance targeted those dimensions of most relevance for an in-depth understanding of teaching practice situations.

Discussion and Conclusion. In general, the tutors appeared to be better at helping students to identify the factors involved in their teaching practice experiences than they were in aiding their understanding through the identification and analysis of the characteristic dilemmas involved in these situations.

Keywords: Reflective practice; tutor assistance with reflective practice; student teachers; dilemmatic knowledge. 


\section{Intervención educativa para mejorar la práctica reflexiva en estudiantes de Magisterio}

\section{Resumen}

Introducción. Algunos resultados de la investigación educativa de los últimos años indican que la reflexión conjunta puede mejorar la reflexión de los estudiantes de maestro sobre las situaciones de la práctica, si cuentan con ayuda adecuada del tutor. Este estudio tiene como objetivos identificar y caracterizar la ayuda ofrecida por los tutores de la universidad en situaciones de reflexión conjunta en el Prácticum y analiza su contribución al desarrollo de su capacidad reflexiva sobre las situaciones de la práctica docente.

Método. Se trata de un estudio de caso. Se centra en el análisis de un proceso de reflexión conjunta de dos grupos de estudiants de maestro (13 y 15 estudiantes) y sus tutores en la universidad durante cinco semanas del Prácticum. Se llevó a cabo un doble análisis de los datos registrados en video: análisis de la interactividad y análisis de Contenido, ambos para examinar las formas de ayuda del tutor a la reflexión sobre la práctica.

Resultados. Cada tutor distribuyó sus ayudas a la reflexión conjunta de modo específico, centrándolas en aspectos característicos de la reflexión diferentes, priorizando su intervención en algunas de las dimensiones de la reflexión. Se encontraron también diferencias en el tipo y cantidad de la ayuda ofrecida en cada dimensión de la reflexión. Asimismo los tutores mostraron diferencias en ofrecer ayudas a la reflexión focalizadas en aquellas dimensiones relevantes para la interpretación en profundidad de las situaciones de la práctica.

Discusión y Conclusión. En general, los tutores mostraron una mayor competencia en ayudar a los alumnos a identificar los factores de las situaciones de la práctica y una mayor dificultad en asistirles en la interpretación de las situaciones analizadas mediante la identificación y el análisis de los dilemas que las caracterizan.

Palabras Clave: Práctica reflexiva; ayudas del tutor a la reflexión; estudiantes de maestros; conocimiento de los dilemas. 


\section{Introduction}

Almost all current teacher training programmes include the development of reflective practices as a fundamental thinking process for teachers (Rasmussen, 2008; Ward \& McCotter, 2004). However, there is no body of commonly accepted knowledge on which a model of reflection might be based, and nor do we really understand how the learning of this reflection might be promoted.

Classical authors like Dewey $(1933,1938)$ and Schön $(1983,1987)$ agree that reflection responds to the need to make an indeterminate situation a clearly determinate one. For these authors, the origin of reflection lies in a state of doubt, hesitation, perplexity and mental difficulty, out of which a process of searching and inquiry aims to resolve the difficulty and understand an initially ambiguous situation. According to Dewey, reflection involves a dual process of analysis and synthesis: analysis entails focusing one's thinking on one of the factors in the situation, while synthesis involves placing the various factors in context, in their relation to the other factors in the situation so that the situation becomes an articulated whole. Synthesis thus allows us to understand the internal relationships of the situation and the tensions between its factors that make it problematic. Some authors (Mälkki, 2012; Pareja-Roblin \& Margalef, 2011; Yoon \& Kim, 2010) have pointed out that in educational situations these internal tensions between situational factors result in dilemmas for the teacher, understood as "conflicts and opposing tendencies within oneself that require a deliberation between multiple, equally viable and sometimes unattractive alternatives" (Pareja-Roblin, \& Margalef, 2011, p.19). Clandinin (1986) emphasized the dilemmatic nature of teachers' knowledge, and Cochran-Smith and Lytle (1999) argued that the process of inquiry among teachers has more to do with understanding and explaining dilemmas than with finding solutions. In other words, in the field of education the clarification through reflection of the internal tensions that characterize situations requires both the clarification and understanding of the dilemmas that teachers face and which are intrinsic to these situations. Other authors have added that in this dual process of analysis and synthesis, reflection should also establish connections between the situation reflected upon and broadranging theoretical knowledge of an academic nature; in this respect, reflection constitutes a crucial tool for the construction of professional knowledge (Korthagen, 2001, 2010; Oner, \& Adadan, 2011). Any given reflection process may therefore be characterized according to three dimensions: 1) the degree to which the various factors intervening in the situation are 
identified and understood (analysis); 2) the degree to which tensions between these factors and the dilemmas they create for the teacher are clarified and understood (synthesis); and 3) the degree to which the situation is connected with academic knowledge.

Some authors (Bain, Mills, Ballantyne, \& Packer, 2002; Grossman, 2008; Hatton \& Smith, 1995; LaBoskey, 1994; Moore-Russo \& Wilsey, 2014, Van Manen, 1977; Zeichner \& Liston, 1996) have used similar dimensions (similar especially to the aforementioned dimensions 1 and 3) to characterize levels of reflection among student teachers. Their results indicate that the development of students' reflective capacities requires educational assistance. Thus, processes of individual reflection carried out without support structures (Dawson, 2006; Delandshere \& Arens, 2003; Hamlin, 2004) lead to lower levels of reflection than do processes with structural support (Chamoso \& Cáceres, 2009; Chitpin, Simon, \& Galipeau, 2008; Liakopoulou, 2012; Seban, 2009), and the latter, in turn, produce lower levels than do processes of joint reflection carried out with the aid of knowledgeable others (Gelfuso, \& Dennis, 2014; Samuels \& Betts, 2007). However, the results also show that the mere presence of educational assistance is not sufficient to promote high levels of reflection (Davis, 2006; Gelfuso \& Dennis, 2014; Harford \& MacRuairc, 2008; Postholm, 2008; Wopereis, Sloep, \& Poortman, 2010; Yoon \& Kim, 2010), even if it is combined with processes of joint reflection, or if means (e.g., weblogs, videos) and artefacts (portfolios, journals, logbooks, etc.) that favour it are available.

In this regard, although increasing attention is being paid to providing future teachers with quality experiences that promote reflection (Darling-Hammond \& Lieberman, 2012; Korthagen, 2001; Le Cornu \& Ewing, 2008) many authors continue to wonder how it might best be promoted. Furthermore, the different educational models based on multiple and diverse models of reflection (Akbari, 2007; Gennor, 2005; Ovens \& Tinning, 2009; Thorsen \& DeVore, 2013) present major disagreements regarding the conditions that allow future teachers to learn to reflect (Etscheidt, Curran, \& Sawyer, 2012; Zeichner, 2010).

This article aims to contribute to this debate by presenting two exploratory case studies which describe the distribution of the educational assistance offered by a tutor in a process of joint reflection with student teachers. It also explores hypotheses regarding the relationship between the distribution of this support and the progress that students make in their reflections. 


\section{Teaching proposal}

The study was carried out in the context of a teaching practice module that forms part of a degree in primary education at the University of Barcelona. During the four months that this module lasts, students spend four days a week on placement in schools, while on the fifth day they are required to attend a three-hour seminar at the university.

To support and improve the process of reflection and to help students specifically to interpret their experiences in the practical setting, it was decided to implement a new activity across the first five sessions of the seminar. Half the allotted tutorial time (90 minutes) was dedicated to this activity. The activity began by asking each student to describe, in writing, a situation they had experienced while on placement and which had particularly caught their attention (Roberts, 2009; Scherff \& Singer, 2012). They were told to make their account of the situation as descriptive as possible, presenting the facts without interpreting them, but including any significant dialogues, gestures or movements that were relevant to the situation. The specific instruction was to present their account in such a way that their peers and the seminar tutor would be able to represent the situation as if they had experienced it directly.

Each seminar session began with the chosen student reading aloud his/her account of a situation, and this was followed by a conversation involving all the students, who shared their reactions to what had been described and pointed out the various aspects of the situation that had caught their attention. In terms of their involvement in this conversation the students were asked to focus on understanding what was going on in the situation and why, and to avoid making judgments (positive or negative) regarding the behaviour of those involved in the situation, or suggesting what they should or shouldn't have done.

The university tutor acted as a moderator and, by means of a series of implicit principles for intervening in the conversation, sought to guide students towards the objectives established. These principles focused especially on achieving a multivocal and participatory conversation, one that would assist analysis (identification of intervening factors) and synthesis (comprehension of the tensions and dilemmas) within dialogic joint reflection.

At the end of each of the five scheduled seminar sessions the tutor presented the students with a new situation and asked them to write an individual reflection on it (Smith \& Tillema, 2003; Bain, et al., 2002). Students had to send their written text to the teacher (via 
the Moodle platform) before the next scheduled seminar. This task was intended to serve as an indicator of the progress made in students' reflection over the five weeks.

\section{Method}

\section{Participants}

Two cases were analysed, each corresponding to a group of trainee teachers, currently on placement, and their tutor. Case 1 involved 14 students and the tutor, while Case 2 involved 13 students and the tutor. The students were in their third year of training and this was their second teaching placement in primary schools. The placement lasted for 15 weeks. Both tutors were university lecturers with experience of this role.

The discussion and analysis of the situations they had experienced while on placement took place during the first five tutorial sessions. These sessions lasted for three hours, with around half the allotted time being set aside for this task.

\section{Instruments and Procedure}

Two kinds of data were collected. First, we videoed the whole of the activity involving discussion of all the situations presented in the five sessions. Table 1 shows the duration of the recording for each activity in each session and for both cases.

Table 1

Duration of the activity and the number of accounts analysed in each of the sessions and for both cases

\begin{tabular}{|c|c|c|c|c|c|c|c|c|}
\hline & & Session 1 & Session 2 & Session 3 & Session 4 & Session 5 & Total & Mean \\
\hline \multirow[t]{2}{*}{$\begin{array}{l}\text { Case } \\
1\end{array}$} & $\begin{array}{l}\text { Duration of the } \\
\text { activity }\end{array}$ & $1 \mathrm{~h} 33^{\prime}$ & 0 h 45' & $1 \mathrm{~h} 17^{\prime}$ & $1 \mathrm{~h} 32^{\prime}$ & $1 \mathrm{~h} 54^{\prime}$ & $7 \mathrm{~h} \mathrm{1}{ }^{\prime}$ & 1 h 24' \\
\hline & $\begin{array}{l}\mathrm{N}^{\circ} \text { of situations } \\
\text { analysed }\end{array}$ & 3 & 2 & 3 & 3 & 3 & 14 & 3 \\
\hline \multirow[t]{2}{*}{$\begin{array}{l}\text { Case } \\
2\end{array}$} & $\begin{array}{l}\text { Duration of the } \\
\text { activity }\end{array}$ & 1 h $16^{\prime}$ & 0 h 44' & 0 h $35^{\prime}$ & 0 h $30^{\prime}$ & 2 h 2' & 5 h 7' & $1 \mathrm{~h} 1^{\prime}$ \\
\hline & $\begin{array}{l}\mathrm{N}^{\circ} \text { of situations } \\
\text { analysed }\end{array}$ & 2 & 1 & 1 & 1 & 3 & 8 & 1.6 \\
\hline
\end{tabular}

The second source of data was the documents in which the students (individually and after each session) had written down their reflections about the new practice-based situations proposed by the tutors. There were a total of 61 documents in Case 1, and 54 documents in Case 2.

\section{Data analysis}


The analysis of video recordings involved a content analysis of the tutor's discourse in each of the activities. The aim here was to identify the kinds of discursive assistance offered by both tutors to promote students' reflection.

In order to develop a category system for analysing discursive assistance, we started from the guidelines given to tutors within the context of the teaching proposal, and then carried out a back-and-forth comparison of these guidelines with the data. The final category system included six types of discursive assistance that could be offered by tutors: 1) promoting and raising students' awareness of the various factors involved in the situation; 2) promoting and helping students to identify the dilemmas present in the situation; 3) helping students to link the situation being discussed with the academic knowledge acquired during the theoretical part of their degree course; 4) promoting an interpretative (as opposed to an evaluative or judgmental) approach to the proposed situation; 5) helping students to relate the situation being discussed with other practice-based situations that share one or more relevant feature; and 6) helping students by revisiting and summarizing different elements that emerge during the discussion. Table 2 shows the final category system that was used and gives some examples of teacher discourse for each category.

Table 2

The category system used to analyse the discursive assistance offered by tutors (with examples)

\begin{tabular}{|c|c|c|}
\hline $\begin{array}{l}\text { Type of } \\
\text { assistance }\end{array}$ & Aim & Example \\
\hline Factors & Help to see factors & $\begin{array}{l}\text { You mentioned some elements for understanding the } \\
\text { situation. What other elements might you see here? }\end{array}$ \\
\hline Dilemmas & Help to see dilemmas & $\begin{array}{l}\text { There is a tension between the time I have and the pace of } \\
\text { classroom work, and the pressure coming from the school } \\
\text { to complete a certain syllabus }\end{array}$ \\
\hline Academic & $\begin{array}{l}\text { Help to use academic } \\
\text { knowledge }\end{array}$ & $\begin{array}{l}\text { This seems like a punishment, doesn't it? What do you } \\
\text { know about punishment, what have you learnt during your } \\
\text { degree? }\end{array}$ \\
\hline Interpretative & $\begin{array}{l}\text { Promote an interpretative } \\
\text { view }\end{array}$ & $\begin{array}{l}\text { Don't tell me what you would do, first let's understand } \\
\text { what's happening and why }\end{array}$ \\
\hline Situations & $\begin{array}{l}\text { Promote analogies with } \\
\text { other situations }\end{array}$ & $\begin{array}{l}\text { Do you see anything here that reminds you of the situation } \\
\text { discussed in our last seminar? }\end{array}$ \\
\hline Summary & Summarize ideas & $\begin{array}{l}\text { You've mentioned a number of things: you've talked about } \\
\text { the culture of the school, the teacher's expectations, the } \\
\text { kind of activities, etc. }\end{array}$ \\
\hline
\end{tabular}


The unit of analysis for applying this category system was turn-taking: in other words, the task was to identify the type of assistance that appeared each time the tutor took a turn to speak. It was assumed that for a given turn by the tutor, one, several or none of the types of assistance (categories) could appear. In order to calculate the frequency of each type of assistance, for each session we counted the number of turns in which each of the categories could be observed. This enabled us to calculate the absolute and relative frequencies of assistance in each session.

The individual texts produced by the students after each session underwent content analysis in order to evaluate how individual reflections by students improved during the five sessions. Specifically, we considered five aspects or dimensions: 1) whether the student identified various factors that were involved in the situation being analysed; 2) whether the student identified tensions and dilemmas in the situation; 3) whether the student used academic knowledge in a relevant and substantive way to improve his/her understanding of the situation; 4) whether the student adopted an interpretative (as opposed to an evaluative or judgmental) approach to the situation; and 5) whether the student indicated any additional information that would be needed in order to better understand the situation.

The unit of analysis here was the full text, with each of the above aspects being considered as either present or absent. Thus, we evaluated, for example, whether in the text as a whole the student identified two or more factors that were present in the situation, or whether reference was made to additional information that would be needed in order to better understand the situation. The specific criteria used for this analysis are shown in Table 3.

Table 3.

The criteria used for the content analysis of the students' individual texts

\begin{tabular}{ll}
\hline Dimension & Description \\
Factors & The student explicitly identifies two or more factors to explain the situation \\
Dilemmas & The student explicitly identifies a dilemma or tension that could explain the problem \\
& featured in the situation \\
Tcademic & The student uses academic knowledge in order to understand one or more aspects of the \\
& situation. The academic knowledge used by the student is relevant and helps to \\
understand better a significant aspect of the situation & The student takes an interpretative approach to the situation, with the primary aim of \\
Interpretation & understanding what is happening and why (as opposed to judging the teacher's actions \\
& $\begin{array}{l}\text { in the situation as "good or "bad", or proposing a "solution" to the situation prior to or } \\
\text { without any analysis and understanding) } \\
\text { The student identifies some additional key information that would be needed to better } \\
\text { understand the situation }\end{array}$ \\
\hline
\end{tabular}


Based on this evaluation we then calculated the percentage of students who, for each situation (session), achieved a favourable score on each of the aspects considered. This enabled us to observe the extent to which, if at all, the students' ability to reflect on situations had improved across the five sessions.

The protocol for analysing both the video recordings and the students' individual texts was based on a systematic procedure whose goal was to achieve inter-rater consensus regarding the identification and assignment of categories. This procedure was applied to a random selection of data (video recordings and individual texts) corresponding to different activity sessions. Independent raters assigned categories to the data and compared their results, with any disagreements being discussed so that the corresponding operational criteria could be refined. In the event of persistent disagreement, a third rater acted as arbitrator.

Having established the protocol, we then assessed the mean inter-rater reliability. This was done by calculating Cohen's kappa index for a data sample corresponding to the independent coding of $30 \%$ of the respective units of analysis (turn-taking by the tutor in the case of the video recordings, and full texts in the case of the students' individual texts). The reliability obtained was above .9 for all the categories analysed. All the analyses were performed using Atlas.ti 7.

\section{Results}

\section{Results regarding the progression of individual reflection by students}

Tables 4 and 5 and Figures 1 and 2 show the percentage of students who achieved each dimension in each week, in other words, how the five dimensions considered when analysing the students' individual texts evolved across the five weeks. Figure 1 and Table 4 correspond to Case 1, and Figure 2 and Table 5 to Case 2. 


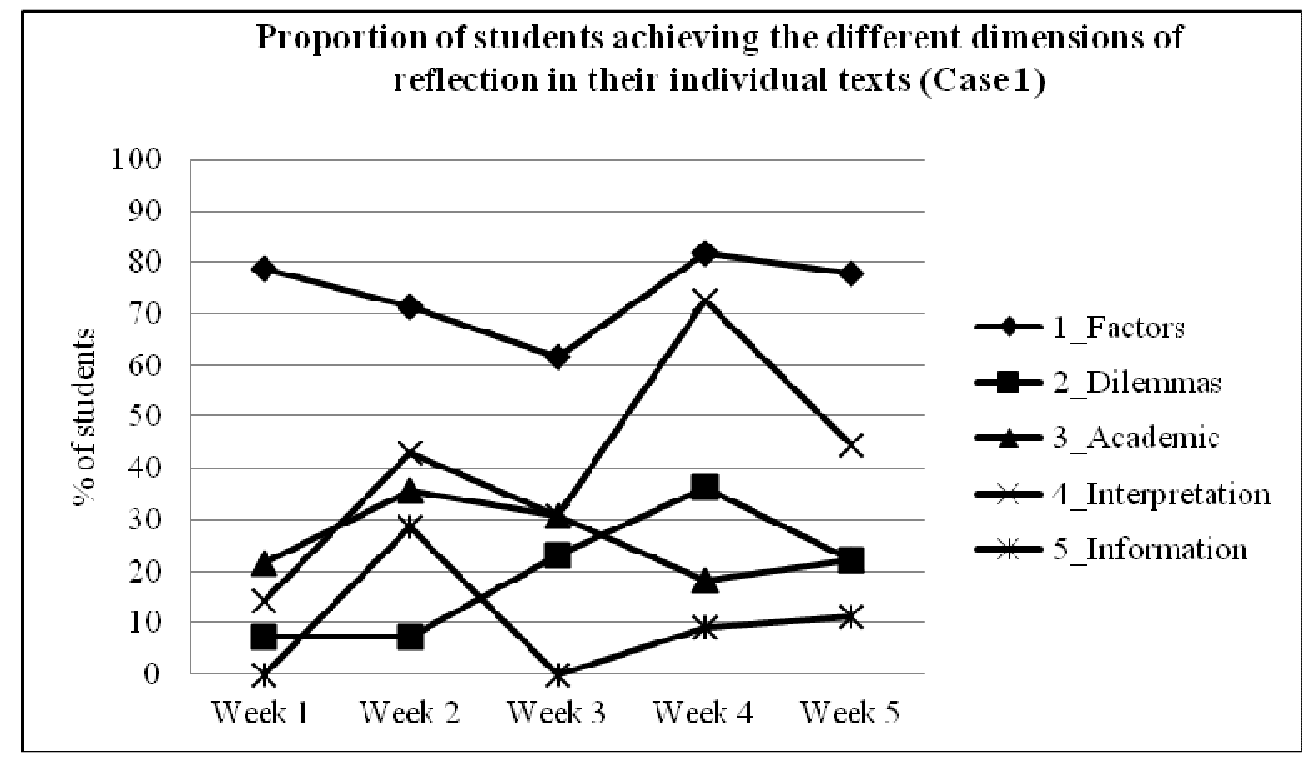

Figure 1. Proportion of students achieving the different dimensions of reflection in their individual texts (Case 1)

Table 4

Proportion of students (\%) achieving the different dimensions of reflection in their individual texts (Case 1)

\begin{tabular}{llllll} 
& Factors & Dilemmas & Academic & Interpretation & Information \\
\hline Week 1 & 78.57 & 7.14 & 21.43 & 14.29 & 0.00 \\
Week 2 & 71.43 & 7.14 & 35.71 & 42.86 & 28.57 \\
Week 3 & 61.54 & 23.08 & 30.77 & 30.77 & 0.00 \\
Week 4 & 81.82 & 36.36 & 18.18 & 72.73 & 9.09 \\
Week 5 & 77.78 & 22.22 & 22.22 & 44.44 & 11.11 \\
\hline
\end{tabular}

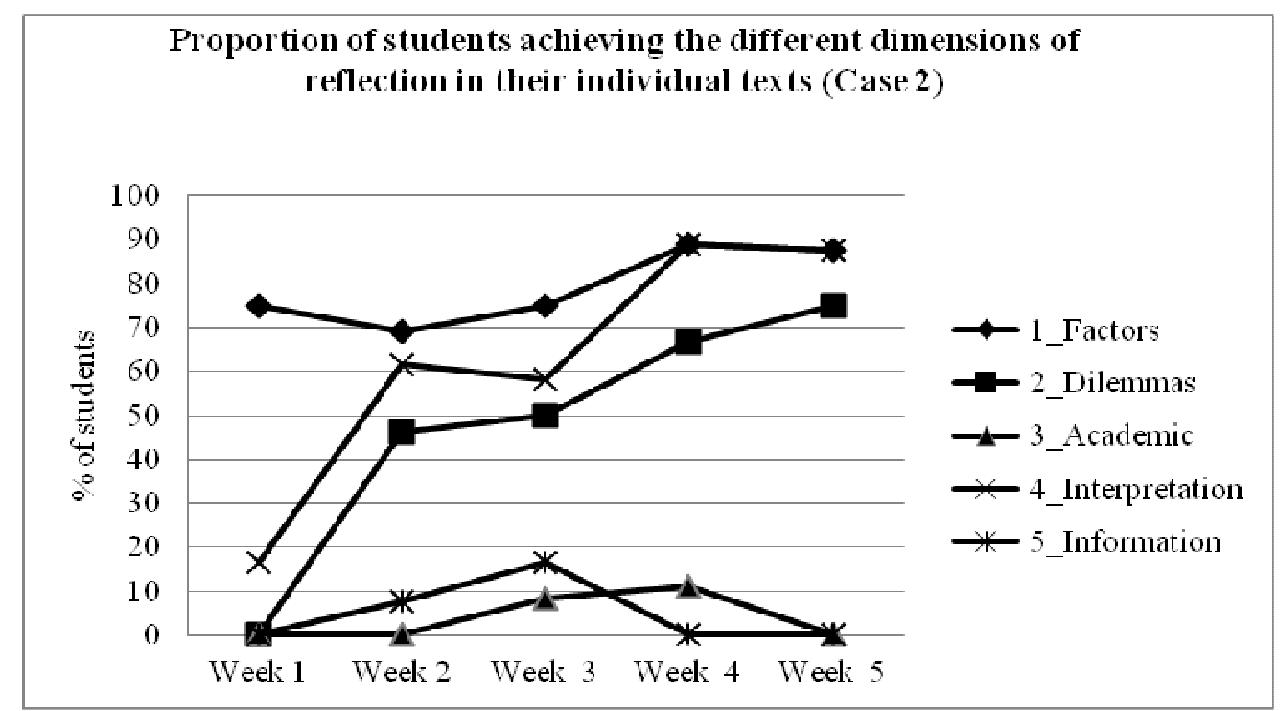

Figure 2. Proportion of students achieving the different dimensions of reflection in their individual texts (Case 2) 
Table 5.

Proportion of students (\%) achieving the different dimensions of reflection in their individual texts (Case 2)

\begin{tabular}{llllll} 
& Factors & Dilemmas & Academic & Interpretation & Information \\
\hline Week 1 & 75.00 & 0.00 & 0.00 & 16.67 & 0.00 \\
Week 2 & 69.23 & 46.15 & 0.00 & 61.54 & 7.69 \\
Week 3 & 75.00 & 50.00 & 8.33 & 58.33 & 16.67 \\
Week 4 & 88.89 & 66.67 & 11.11 & 88.89 & 0.00 \\
Week 5 & 87.50 & 75.00 & 0.00 & 87.50 & 0.00 \\
\hline
\end{tabular}

According to these results, the two dimensions on which the greatest progress was made across the five weeks were, in both cases, Interpretation and Dilemmas, although Interpretation always achieved a higher value than the Dilemmas dimension. The progress made in relation to these two dimensions was notably stronger in Case 2 (Interpretation: $16.67 \%$ to $87.50 \%$; Dilemmas: $0 \%$ to $75 \%$ ) than in Case 1 (Interpretation: $14.29 \%$ to $44.44 \%$; Dilemmas: $7.14 \%$ to $22.22 \%$ ). The Factors dimension achieved high values in both cases from the outset and maintained these levels across the five weeks, whereas the values for the other two dimensions, Academic and Information, remained low in both cases across the fiveweek period, although values for both these dimensions were higher in Case 1 than in Case 2 .

\section{Descriptive results regarding tutor assistance with the process of joint reflection}

Tables 6 and 7 show several descriptive indicators regarding the process of joint reflection and the assistance offered by the tutor during this process. Table 6 shows the results for Case 1, while Table 7 corresponds to Case 2.

Table 6.

Descriptive indicators of joint reflection in Case 1

\begin{tabular}{lllllll} 
& Week 1 & Week 2 & Week 3 & Week 4 & Week 5 & Total \\
\hline $\begin{array}{l}\text { Number of situations worked } \\
\text { on }\end{array}$ & 3 & 2 & 3 & 3 & 3 & 14 \\
$\begin{array}{l}\text { Number of assistance turns by } \\
\text { the tutor }\end{array}$ & 41 & 21 & 26 & 46 & 46 & 180 \\
$\begin{array}{l}\text { Mean number of assistance } \\
\text { turns by the tutor per situation }\end{array}$ & 13.7 & 10.5 & 12 & 15.3 & 15.3 & 12.8 \\
$\begin{array}{l}\text { Total time spent on joint } \\
\text { reflection }\end{array}$ & $1: 33: 00$ & $0: 45: 00$ & $1: 17: 00$ & $1: 32: 00$ & $1: 54: 00$ & $7: 01: 00$ \\
$\begin{array}{l}\text { Time devoted to assistance } \\
\text { Proportion of joint reflection }\end{array}$ & $00: 24: 01$ & $00: 12: 36$ & $00: 29: 23$ & $00: 32: 48$ & $00: 29: 13$ & $2: 08: 01$ \\
$\begin{array}{l}\text { time devoted to assistance } \\
\text { Mean time devoted per turn of }\end{array}$ & $00: 00: 35$ & $00: 00: 36$ & $00: 01: 08$ & $00: 00: 43$ & $00: 00: 38$ & $00: 00: 43$ \\
assistance & & & & & & \\
\hline
\end{tabular}


Table 7

Descriptive indicators of joint reflection in Case 2

\begin{tabular}{lllllll} 
& Week 1 & Week 2 & Week 3 & Week 4 & Week 5 & Total \\
\hline $\begin{array}{l}\text { Number of situations worked } \\
\text { on }\end{array}$ & 2 & 1 & 1 & 1 & 3 & 8 \\
$\begin{array}{l}\text { Number of assistance turns by } \\
\text { the tutor }\end{array}$ & 26 & 37 & 23 & 15 & 64 & 165 \\
$\begin{array}{l}\text { Mean number of assistance } \\
\text { turns by the tutor per situation }\end{array}$ & 13 & 37 & 23 & 15 & 21.3 & 20.6 \\
$\begin{array}{l}\text { Total time spent on joint } \\
\text { reflection }\end{array}$ & $1: 16: 00$ & $0: 44: 00$ & $0: 35: 00$ & $0: 30: 00$ & $2: 02: 00$ & $5: 07: 00$ \\
$\begin{array}{l}\text { Time devoted to assistance } \\
\text { Proportion of joint reflection } \\
\text { time devoted to assistance }\end{array}$ & $00: 32: 12$ & $00: 26: 06$ & $00: 11: 22$ & $00: 14: 00$ & $00: 52: 47$ & $2: 16: 28$ \\
$\begin{array}{l}\text { Mean time devoted per turn of } \\
\text { assistance }\end{array}$ & $00: 01: 14$ & $00: 00: 42$ & $00: 00: 30$ & $00: 00: 56$ & $00: 00: 49$ & $00: 00: 50$ \\
\hline
\end{tabular}

These results reveal a major difference between Case 1 and Case 2 as regards the amount of assistance offered by the tutor during the process of joint reflection. Specifically, the total number of assistance turns was higher in Case 1 than in Case 2 (180 vs. 165). However, the total amount of time that the tutor devoted to assistance was similar in the two cases (Case 1: 2 h 08'; Case 2: 2 h 16').

Notably, there were major differences between the two cases in the total amount of

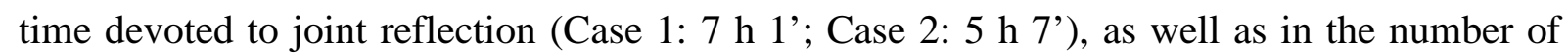
situations worked on (Case 1: 14; Case 2: 8). This means that although the assistance data for the two cases are similar in absolute terms, they are very different when considered in relative terms. Specifically, the proportion of joint reflection time devoted to tutor assistance was much higher in Case 2 (63.8\%) than in Case 1 (30.4\%). Similarly, the mean number of assistance turns by the tutor per situation was much higher in Case 2 (20.6) than in Case 1 (12.8).

\section{Results for the distribution of assistance offered by the university tutor}

Table 8 show the proportion of assistance turns that tutors in Case 1 and Case 2 devoted to each kind of assistance across the whole process of joint reflection. 
Table 8

Proportion (\%) of assistance turns by the tutor in Case 1 and Case 2

\begin{tabular}{lll} 
& Case 1 & Case 2 \\
\hline Factors & 26.66 & 8.42 \\
Dilemmas & 22.5 & 28.83 \\
Academic & 9.58 & 13.27 \\
Interpretation & 7.92 & 14.54 \\
Situations & 5.42 & 7.14 \\
Summary & 27.92 & 27.80 \\
\hline
\end{tabular}

These results show that the tutor in Case 2 devoted more time to Interpretative, Dilemmas and Academic assistance than the tutor in Case 1, whereas the tutor in Case 1 devoted much more time to Factors assistance than the tutor in Case 2. The proportion of assistance devoted to the Summary and Situations dimensions was similar in the two cases. Tables 9 and 10 show the proportion of assistance turns that tutors devoted to each kind of assistance in each weekly session. Table 9 shows the results for Case 1, while Table 10 shows the results for Case 2 .

Table 9

Proportion (\%) of assistance turns devoted per week to each type of assistance by the tutor in Case 1

\begin{tabular}{llllll} 
& Week 1 & Week 2 & Week 3 & Week 4 & Week 5 \\
\hline Factors & 23.64 & 12.00 & 27.50 & 34.43 & 27.12 \\
Dilemmas & 29.09 & 52.00 & 15.00 & 14.75 & 16.95 \\
Academic & 0.00 & 0.00 & 7.50 & 19.67 & 13.56 \\
Interpretati & 16.36 & 8.00 & 7.50 & 3.28 & 5.08 \\
on & & & & & \\
Situations & 1.82 & 0.00 & 12.50 & 3.28 & 8.47 \\
Summary & 29.09 & 28.00 & 30.00 & 24.59 & 28.81 \\
\hline
\end{tabular}

Table 10

Proportion (\%) of assistance turns devoted per week to each type of assistance by the tutor in Case 2

\begin{tabular}{llllll} 
& Week 1 & Week 2 & Week 3 & Week 4 & Week 5 \\
\hline Factors & 11.29 & 2.27 & 10.42 & 13.46 & 8.45 \\
Dilemmas & 20.97 & 12.50 & 37.50 & 34.62 & 37.32 \\
Academic & 6.45 & 42.05 & 4.17 & 3.85 & 4.93 \\
Interpretation & 29.03 & 11.36 & 20.83 & 9.62 & 9.86 \\
Situations & 4.84 & 1.14 & 6.25 & 1.92 & 14.08 \\
Summary & 27.42 & 30.68 & 20.83 & 36.54 & 25.35 \\
\hline
\end{tabular}


In Case 1 there was a high proportion of Dilemmas assistance in week 2 (52\%), but the presence of this kind of assistance then decreased substantially during weeks 3,4 , and 5 (staying around 15\%). Assistance with Summary was frequent and sustained across the five weeks (between 25\% and 30\%), while the proportion of Factors assistance was also high and remained between $23 \%$ and $35 \%$ in weeks 1, 3, 4 and 5 (week 2 was an exception here). The proportions of Interpretative and Situation assistance were quite low across the five weeks. Finally, no Academic assistance was given at all in weeks 1 and 2, although its presence then increased substantially during the remaining three weeks; however, it always remained below $20 \%$.

In Case 2 there was a high proportion of Academic assistance in week 2 (42.05\%), but this kind of assistance had a minimal presence (below 5\%) in weeks 1, 3, 4 and 5. Assistance with Summary was frequent and sustained across the five weeks (between 20\% and 36\%). Dilemma assistance was also common and sustained (between 20\% and 37\%) in weeks 1, 3, 4 and 5 (with week 2 being an exception), and it was especially present and sustained during the last three weeks (between $34.62 \%$ and $37.32 \%$ ). The proportion of Interpretative assistance, although not especially high, remained between $10 \%$ and $30 \%$ across the five weeks. By contrast, the proportions for both Factors and Situation assistance were quite low across all five weeks.

\section{Summary of the results}

The results suggest that the processes of joint reflection conducted in both cases helped students to make progress in relation to the Interpretation and Dilemma dimensions, although of the two the values for Interpretation were always higher in both cases and across all five weeks. It should also be noted that progress in relation to these two dimensions was considerably more marked in Case 2 than in Case 1. The results also suggest that students find it relatively easy to recognize the Factors of situations from the outset, since the values for this dimension (see Table 5: Factors) were very high in all five weeks and in both cases. Conversely, the results also suggest that the process of joint reflection did not help to develop the Academic and Information dimensions, which present low values in both cases across all five weeks.

The proportion of assistance offered by the tutor during the processes of joint reflection differed between Case 1 and Case 2. Specifically, it was much higher in Case 2, 
both from the point of view of the proportion of time devoted to assistance and in terms of the mean number of assistance turns that the tutor took in each situation. However, the total amount of time devoted to the whole process of joint reflection, as well as the number of situations worked on, were both higher in Case 1 than in Case 2.

The results also reveal differences between the two cases in the distribution of assistance. In both cases the tutor made a sustained effort to offer Summary assistance. However, whereas in Case 1 a sustained effort was also made in relation to Factors assistance, this kind of assistance was infrequent in Case 2, with a greater sustained effort being directed instead towards Dilemmas assistance. Although in Case 1 a considerable amount of Dilemmas assistance was offered in week 2, this effort was not sustained across the five weeks, and the relative proportions of this kind of assistance were low in weeks 1, 3, 4 and 5 . A similar pattern can be observed in Case 2 with respect to Academic assistance, which had a strong presence in week 2 but was infrequent in weeks 1, 3, 4 and 5. Academic assistance also showed a minimal presence in Case 1 across all five weeks. Finally, in both Cases 1 and 2 the proportion of Situation assistance remained low across the five weeks.

\section{Discussion and Conclusions}

The results of this study support those of previous research which found that participation in processes of joint reflection allows students to develop reflective skills provided that they receive specifically tailored assistance over the course of the process (Davis, 2006; Gelfuso \& Dennis, 2014; Harford \& MacRuairc, 2008; Postholm, 2008; Wopereis, Sloep, \& Poortman, 2010; Yoon \& Kim, 2010). Our findings therefore confirm the importance of assistance for the development of joint reflection.

However, not all kinds of assistance are equally useful. Our results show that although students in both cases made progress in their joint reflection processes, the effect was much greater in Case 2 than in Case 1. Obviously, the design of the study (i.e. a case study) prevents us from establishing relationships that might explain these differences (to do so, a quasiexperimental study would be required). Nonetheless, the results about the processes of joint reflection in the two cases can be used to formulate hypotheses that can be tested in future studies. 
The first hypothesis regarding why Cases 1 and 2 differed in terms of the amount of progress made in joint activity concerns the level of tutor intervention. One of our findings was that the tutor in Case 2 used $63.8 \%$ of the total joint reflection time to talk to students and offer them assistance, whereas the corresponding proportion of time in Case 1 was $30.4 \%$. Obviously, this also means that students talked proportionally more in Case 1 than in Case 2. A possible partial explanation of the results would therefore be that students in Case 2 made greater progress than their peers in Case 1 because their joint reflection process included a much higher proportion of assistance from their tutor. However, although this may be partially true for our data, we would argue that such an explanation is not fully generalizable. This is because numerous studies have documented that a high degree of interventionism by the teacher in educational interactions does not always foster students' learning, and may in fact inhibit it (Dillenbourg, 2002; Rienties et al., 2012). Indeed, many authors have argued that the distribution of talk in educational situations should be inverted, such that the students rather than the teacher are the main protagonists (Cazden, 2001; Lemke, 1990). In our view, the degree to which the teacher intervenes in joint reflection can be an important factor when it comes to explaining learning, but the extent of its influence will depend on the nature of this intervention. In other words, we suggest that the proportion of assistance alone cannot explain differences in the progress made by students in their reflective practice, although it may become an important explanatory factor if it is combined with a certain kind and a certain distribution of assistance in teacher and student interactions and peer interaction (van de Pol, Volman, \& Beishuizen, 2010).

Interestingly, the distribution of assistance did differ between the two cases studied: in Case 1 a more sustained effort was made in relation to Factors assistance, whereas in Case 2 the most sustained effort concerned Dilemmas assistance. Furthermore, although the proportion of Interpretative assistance was not especially high, it was greater in Case 2 than in Case 1. This suggests another partial explanation for the progress we observed in students' joint reflection: the Dilemma and Interpretation dimensions showed greater progress in Case 2 than in Case 1 because in the former a higher proportion of assistance was targeted at these specific dimensions. On the other hand, in Case 1 little progress was observed in relation to Factors - despite the tutor's efforts in this regard - because a high proportion of students could already fulfil the criteria for this dimension at the outset; in other words, they did not need this kind of assistance. This explanation of our data suggests that in processes of joint reflection, the assistance offered by tutors should be aimed specifically at what Dewey (1933) 
called "synthesis" rather than "analysis", since students (at least in our two cases) seem to find it much easier to identify the different factors involved in a situation than to see the tensions and dilemmas that are established among them.

Another point to be made about the distribution of assistance concerns the degree to which assistance is sustained. Our results show, for example, that in the second week of Case 2 the tutor made an enormous effort to offer Academic assistance, whereas this kind of assistance was barely present in the other four weeks. Interestingly, students in Case 2 made no progress in relation to the Academic dimension. Similarly, in the second week of Case 1 the tutor devoted a considerable amount of time to Dilemmas assistance, whereas in the remaining weeks this kind of assistance was notably less frequent, even though it did maintain a certain presence. As we have already noted, although the students in Case 1 made progress in relation to the Dilemmas dimension, this progress was considerably less than that achieved by their peers in Case 2. These results are consistent with an idea already put forward by several authors regarding the importance of the temporal dimension in the processes of educational assistance (Coll, Onrubia, \& Mauri, 2008; Mercer, 2008; van de Pol, Volman, \& Beishuizen, 2010): namely that in order to be effective, assistance must be sustained throughout the educational process (in our case the process of joint reflection) and must be adapted to or contingent upon the students' activity.

Some of the dimensions considered in this study remain unexplored in our analysis because students did not show progress in them, and tutors did not offer much assistance in relation to them. In our view, the most important of these dimensions is the Academic one, where we observed no progress among students and an absence of sustained assistance among tutors. This is clearly a limitation of our study, and should be a point of departure for future research. The small number of cases is another limitation. Further research is also required to examine in greater detail the relationships between assistance and progress; one focus for this research would be to test the hypotheses proposed above. Finally, we believe it is also necessary to characterize the nature of assistance in more detail, specifically by considering the turns taken by the tutor in relation to those taken by students. A key objective here would be to learn more about the effect of the tutor's interventions and the distribution of talk among students and teacher in processes of joint reflection. 
Despite the limitations of this study, its findings contribute to the literature on teacher education and reflection by offering some insights into the characteristics of assistance that can improve students' reflection by means of joint reflection processes. Our exploratory results point to two such characteristics: 1) assistance should be focused particularly on what Dewey called "synthesis", since students do not seem to require much assistance with "analysis"; 2) the level of assistance given to a specific aspect of reflection (for example, to synthesis) should be sustained throughout the process if it is to have a substantial influence on students' reflection.

\section{Acknowledgements}

This research was funded by the Ministerio de Economía y Competitividad, Gobierno de España (Ministry of Economy and Competitiveness, Spanish Government), (EDU201344632-P. It was also funded by the Agència d'Ajuts Universitaris i de Recerca (Agency of University and Research Grants) (AGAUR), Generalitat de Catalunya (Generalitat of Catalonia), (2014 ARMIF 00052).

\section{References}

Akbari, R. (2007). Reflections on reflection: A critical appraisal of reflective practices in L2 teacher education. System, 35(2), 192-207. doi:10.1016/j.system.2006.12.008

Bain, J. D., Mills, C., Ballantyne, R., \& Packer, J. (2002). Developing Reflection on Practice Through Journal Writing: Impacts of variations in the focus and level of feedback. Teachers and Teaching, 8(2), 171-196. doi:10.1080/13540600220127368

Cazden, C. B. (2001). Classroom Discourse: The Language of Teaching and Learning. Portsmouth, NH: Heinemann.

Chamoso, J. M., \& Cáceres, M. J. (2009). Analysis of the reflections of student-teachers of mathematics when working with learning portfolios in Spanish university classrooms. Teaching and Teacher Education, 25, 198-206. doi:10.1016/j.tate.2008.09.007

Chitpin, S., Simon, M., \& Galipeau, J. (2008). Pre-service teachers'use of the objective knowledge framework for reflection during practicum. Teaching and Teacher Education, 24, 2049-2058. doi:10.1016/j.tate.2008.04.001

Clandinin, D. J. (1986). Classroom practice: Teacher images in action. Philadelphia: The Falmer Press. 
Coll, C., Onrubia, J., \& Mauri, T. (2008). Ayudar a aprender en contextos educativos: el ejercicio de la influencia educative y el análisis de la enseñanza. Revista de Educación, 364.Mayor-agosto, 2008, 33-70

Cochran-smith, M., \& Lytle, S. L. (1999). Relationships of Knowledge and Practice: Teacher Learning in Communities. Review of Research in Education, 24, 249-305. doi:10.2307/1167272

Darling-Hammond, L., \& Leiberman, A. (2012). Teacher education around the world: what can we learn from international practice? In L. Darling-Hammond \& A. Leiberman (Eds.), Teacher education around the world: Changing politics and Practices (pp. 151-169). London: Routledge.

Davis, E. A. (2006). Characterizing productive reflection among preservice elementary teachers: Seeing what matters. Teaching and Teacher Education, 22(3), 281-301. doi:10.1016/j.tate.2005.11.005

Dawson, K. (2006). Teacher Inquiry: A Vehicle to Merge Prospective Teacher' Experience and Reflection during Curriculum-Based Technology-Enhanced Field Experiences. Journal of Research on Technology in Education, 38(3), 265-292. doi:10.1080/15391523.2006.10782460

Delandshere, G., \& Arens, S. A. (2003). Examining the quality of the evidence in preservice teacher portfolios. Journal of Teacher Education, 54(1), 57-73. doi: $10.1177 / 0022487102238658$

Dewey, J. (1933). How we think. Chicago: Henry Regnery.

Dewey, J. (1938). Logic: The Theory of Inquiry. New York: Holt, Rinehart and Winston.

Dillenbourg, P. (2002). Over-scripting CSCL: The risks of blending collaborative learning with instructional design. In P. A. Kirschner (Ed.), Three worlds of CSCL. Can we support CSCL? (pp. 61-91). Heerlen: Open Universiteit Nederland. Retrieved from http://www.ou.nl/documents/Promoties-enoraties/Oraties/Oraties2002/oratieboek_PKI_DEF_Klein_ZO.pdf

Erickson, F. \& Schultz, J. (1977). When is a context? Some issues and methods in the analysis of social competence. Quarterly Newsletter of the Institute for Comparative Human Development, 1, 5-10.

Etscheidt, S., Curran, C. M., \& Sawyer, C. M. (2012). Promoting Reflection in Teacher Preparation Programs: A Multilevel Model. Teacher Education and Special Education, 35(1), 7-26. doi: 10.1177/0888406411420887 
Gelfuso, A., \& Dennis, D. V. (2014). Getting reflection off the page: The challenges of developing support structures for pre-service teacher reflection. Teaching and Teacher Education, 38, 1-11. doi:10.1016/j.tate.2013.10.012

Gennor, M. (2005). A Social Reconstructionist Framework for Reflection: The "Problematizing" of Teaching. Issues in Teacher Education, 14(2), 45-62. Retrieved from http://eric.ed.gov/?id=EJ796414

Grossman, P. (2010). Learning to Practice: The Design of Clinical Experience in Teacher Preparation. Policy Brief Series Document of AACTE \& NEA, May, 1-8. Retrieved from https://www.nea.org/assets/docs/Clinical_Experience_-_Pam_Grossman.pdf

Hamlin, K. D. (2004). Beginning the journey: supporting reflection in early field experiences. Reflective Practice: International and Multidisciplinary Perspectives, 5(2), 167-179. doi:10.1080/14623940410001690956

Harford, J., \& MacRuairc, G. (2008). Engaging student teachers in meaningful reflective practice. Teaching and Teacher Education, 24(7), 1884-1892. doi:10.1016/j.tate.2008.02.010

Hatton, N., \& Smith, D. (1995). Reflection in teacher education: Towards definition and implementation. Teaching and Teacher Education, 11(1), 33-49. doi:10.1016/0742$051 \times(94) 00012-u$

Krippendorff, K. (2013). Content Analysis. An Introduction to Its Methodology. Third Edition London:Sage.

Korthagen, F. (2001). Linking Practice and Theory. The Pedagogy of realistic Teacher Education. New York: Lawrence Erlbaum Associates, Inc.

Korthagen, F. (2010). Situated learning theory and the pedagogy of teacher education: Towards an integrative view of teacher behavior and teacher learning. Teaching and Teacher Education, 26, 98-106. doi:10.1016/j.tate.2009.05.001

LaBoskey, V. K. (1994). Development of reflective practice: A study of preservice teachers. New York: Teachers College Press.

Le Cornu, R., \& Ewing, R. (2008). Reconceptualising professional experiences in pre-service teacher education...reconstructing the past to embrace the future. Teaching and Teacher Education, 24(7), 1799-1812. doi:10.1016/j.tate.2008.02.008

Lemke, J. L. (1990). Talking science. Language, learning and values. Westport: Ablex. Liakopoulou, M. (2012). The Role of Field Experience in the Preparation of Reflective Teachers. Australian Journal of Teacher Education, 37(6), 41-54. doi:10.14221/ajte.2012v37n6.4 
Mälkki, K. (2012). Rethinking Disorienting Dilemmas Within Real-Life Crises : The Role of Reflection in Negotiating Emotionally Chaotic Experiences. Adult Education Quarterly, 62(3), 207-229. doi:10.1177/0741713611402047

Mercer, N. (2008). The Seeds of Time: Why Classroom Dialogue Needs a Temporal Analysis. Journal of the Learning Sciences, 17(1), 33-59. doi:10.1080/10508400701793182

Moore-Russo, D. A., \& Wilsey, J. N. (2014). Delving into the meaning of productive reflection: A study of future teachers' reflections on representations of teaching. Teaching and Teacher Education, 37, 76-90. doi:10.1016/j.tate.2013.10.002

Oner, D., \& Adadan, E. (2011). Use of Web-Based Portfolios as Tools for Reflection in Preservice Teacher Education. Journal of Teacher Education, 62(5), 477-492. doi:10.1177/0022487111416123

Ovens, A., \& Tinning, R. (2009). Reflection as situated practice : A memory-work study of lived experience in teacher education. Teaching and Teacher Education, 25(8), 11251131. doi:10.1016/j.tate.2009.03.013

Pareja Roblin, N., \& Margalef, L. (2013). Learning from dilemmas: teacher professional development through collaborative action and reflection. Teachers and Teaching: Theory and Practice, 19(1), 18-32. doi:10.1080/13540602.2013.744196

Postholm, M. B. (2008). Teachers developing practice: Reflection as key activity. Teaching and Teacher Education, 24(7), 1717-1728. doi:10.1016/j.tate.2008.02.024

Rasmussen, J. (2008). Training teachers in Denmark: Ongoing reforms. Danish submission to the Alliance: School of Education, University of Aarhus.

Rienties, B., Giesbers, B., Tempelaar, D., Lygo-Baker, S., Segers, M., \& Gijselaers, W. (2012). The role of scaffolding and motivation in CSCL. Computers \& Education, 59(3), 893-906. doi:10.1016/j.compedu.2012.04.010

Roberts, A. (2002). Encouraging reflective practice in periods of professional workplace experience: the development of a conceptual model. Reflective Practice: International and Multidisciplinary Perspectives, 10(5), 633-644. doi:10.1080/14623940903290703

Samuels, M., \& Betts, J. (2007). Crossing the threshold from description to deconstruction and reconstruction: using self - assessment to deepen reflection. Reflective Practice: International and Multidisciplinary Perspectives, 8(2), 269-283. doi:10.1080/14623940701289410 
Scherff, L., \& Singer, N. R. (2012). The preservice teachers are watching: Framing and reframing the field experience. Teaching and Teacher Education, 28(2), 263-272. doi:10.1016/j.tate.2011.10.003

Schön, D. (1983). The Reflective practitioner: How Professionals Think in Action. New York: Basic Books.

Schön, D. (1987). Educating The Reflective Practitioner: Toward a New Design for Teaching and Learning in the Professions. San Francisco: Jossey-Bass.

Seban, D. (2009). Researching reflective field practices of elementary pre-service teachers: two-dimensional analysis of teacher narratives. Reflective Practice: International and Multidisciplinary Perspectives, 10(5), 669-681. doi:10.1080/14623940903290745

Smith, K., \& Tillema, H. (2003). Clarifying different types of portfolio use. Assessment \& Evaluation in Higher Education, 28(6), 625-648. doi:10.1080/0260293032000130252

Thorsen, C. A., \& DeVore, S. (2013). Analyzing reflection on / for action : A new approach. Reflective Practice: International and Multidisciplinary Perspectives, 14(1), 88-103. doi:10.1080/14623943.2012.732948

Van de Pol, J., Volman, M., \& Beishuizen, J. (2010). Scaffolding in Teacher-Student Interaction: A Decade of Research. Educational Psychology Review, 22(3), 271-296. doi:10.1007/s10648-010-9127-6

Van Manen, M. (1977). Linking ways of knowing with ways of being practical. Curriculum Inquiry, 6(3), 205-228. doi:10.2307/1179579

Ward, J. R., \& McCotter, S. S. (2004). Reflection as a visible outcome for preservice teachers. Teaching and Teacher Education 20, 243-257. doi:10.1016/j.tate.2004.02.004

Wopereis, I. G. J. H., Sloep, P. B., \& Poortman, S. H. (2010). Weblogs as instruments for reflection on action in teacher education. Interactive Learning Environments, 18(3), 245-261. doi:10.1080/10494820.2010.500530

Yoon, H. G., \& Kim, M. (2010). Collaborative Reflection through Dilemma Cases of Science Practical Work during Practicum. International Journal of Science Education, 32(3), 283-301. doi:10.1080/09500690802516538

Zeichner, K. (2010). Rethinking the Connections Between Campus Courses and Field Experiences in College- and University-Based Teacher Education. Journal of Teacher Education, 61(1-2), 89-99. doi:10.1177/0022487109347671

Zeichner, K., \& Liston, D. (1996). Reflective teaching. Mahwah, NJ: Lawrence Erlbaum. 